\title{
Meningkatkan keterampilan sosial pasien skizofrenia katatonik melalui social skill training
}

\author{
Muhamad Febrian Al-Amin ${ }^{1}$
}

\begin{abstract}
Social interaction in people with schizophrenia is a serious problem, because if it is not treated it will make the situation worse. This case study aims to improve social skills in people with schizophrenia using Social Skills Training. Psychological assessment using interviews, observation, Wechsler Adult Intelligence Scale (WAIS), Graphic Test, and Sack's Sentence Completion Test (SSCT). The subject is 18 year old male. The results of the intervention show changes in the form of being able to say hello, introduce yourself first, interact with people around, and the subject is no longer in the room often.
\end{abstract}

\section{Keywords}

Social skills training, schizophrenia catatonic, social interaction, graphic test

\section{Pendahuluan}

Skizofrenia didefinisikan sebagai penyakit mental dengan gangguan otak yang kompleks. Skizofrenia adalah suatu penyakit pervasif yang mempengaruhi lingkup yang luas dari proses psikologis mencakup kognisi, afek, dan perilaku. Mereka kehilangan jati diri dan mengalami kegagalan dalam menjalankan peran dan fungsinya di lingkungan masyarakat. Pikiran dan perasaan yang tidak seimbang menyebabkan penderita skizofrenia terputus dari realitas (Nevid, 2005).

Skizofrenia berasal dari bahasa Yunani, schizein yang berarti terpisah atau pecah dan phren yang berarti jiwa, sehingga skizofrenia berarti terjadi pecahnya/ketidakserasian antara afek, kognitif, dan perilaku. Skizofrenia adalah suatu psikosa fungsional dengan gangguan utama pada proses pikir serta disharmonisasi antara proses pikir, afek atau emosi, kemauan dan psikomotor disertai distorsi kenyataan, terutama karena waham dan halusinasi, assosiasi terbagi-bagi sehingga muncul inkoherensi, afek dan emosi inadekuat, serta psikomotor yang menunjukkan penarikan diri (Maramis, 2009).

Masyarakat yang masih awam dengan gangguan ini, tidak mengenali fase-fase yang terdapat pada penderita skizofrenia. Pada fase awal atau prodormal penderita terlihat murung, menarik diri dari lingkungannya, sedikit bicara, dan malas dalam beraktivitas, sehingga terjadi penurunan peran dan fungsi dalam sosial kemasyarakatan. Fase ini sering tidak disadari oleh keluarga, teman dekat atau bahkan penderita skizofrenia sendiri. Secara tidak sadar penderita memasuki fase berikutnya yaitu fase akut dimana mereka mengalami waham dan halusinasi.
Gejala skizofrenia dibagi menjadi dua kategori utama yaitu gejala positif dan gejala negatif. Gejala positif terdiri dari delusi (waham), halusinasi dan perilaku aneh (Videbeck, 2008). Gejala negatif (defisit perilaku) meliputi afek tumpul dan datar, menarik diri dari masyarakat, tidak ada kontak mata, tidak dapat mengekpresikan perasaan, tidak mampu berhubungan dengan orang lain, serta motivasi menurun. Gejala negatif pada skizofrenia dapat menyebabkan klien mengalami gangguan fungsi sosial dan isolasi sosial. Gejala positif dapat dikontrol dengan pengobatan, tetapi gejala negatif seringkali menetap sepanjang waktu dan menjadi hambatan utama pemulihan serta perbaikan fungsi dalam kehidupan seharihari (Videbeck, 2008).

Salah satu jenis gangguan skizofrenia yaitu skizofrenia katatonik. Menurut Maramis (2009) skizofrenia katatonik atau disebut juga katatonia, timbulnya pertama kali antara umur 15-30 tahun dan biasanya akut serta sering didahului oleh stres emosional. Terjadi gaduh gelisah katatonik atau stupor katatonik dan ciri diam serta membisu. Pada stupor katatonik, penderita sama sekali tidak menunjukan perhatian terhadap lingkungannya dan emosinya sangat dangkal. Secara tiba-tiba atau perlahan-lahan penderita keluar dari keadaan stupor ini serta mulai berbicara dan bergerak. Pada gaduh gelisah katatonik, terdapat hiperaktivitas motorik, namun tidak disertai dengan emosi

${ }^{1}$ Biro psikologi Logia Consulting, Jalan hibrida ujung no 1,Bengkulu

Korespondensi:

Muhamad Febrian Al-Amin, Biro psikologi Logia Consulting, Jalan hibrida ujung no 1,Bengkulu

Email: mfebrianalamin@gmail.com 
yang semestinya dan tidak dipengaruhi oleh rangsangan dari luar.

Skizofrenia katatonik saat ini jarang ditemukan, mungkin karena terapi obat bekerja secara efektif bagi proses-proses motorik yang aneh tersebut. Meskipun terapi obat mampu bekerja secara efektif, tetap saja hal tersebut sangat dipengaruhi oleh faktor lingkungan dan pembelajaran sosial. Onset reaksi katatonik dapat lebih tiba-tiba dibanding skizofrenia yang lain, meskipun orang yang bersangkutan sebelumnya telah menunjukkan semacam menarik diri dari kenyataan.

Kondisi subjek dengan gangguan skizofrenia katatonik memang banyak tidak mengganggu dan tidak merusak lingkungan, tetapi banyak aktivitas sosial yang terabaikan, salah satu penanganan yang tepat untuk pasien tipe katatonik adalah Social Skills Training (pelatihan keterampilan social). Keterampilan sosial adalah kemampuan individu untuk berkomunikasi secara efektif dengan orang lain baik secara verbal maupun nonverbal sesuai dengan situasi dan kondisi yang ada pada saat itu, di mana keterampilan ini merupakan perilaku yang dipelajari. Gimpel \& Merrell (1998) mendefinisikan keterampilan sosial sebagai perilaku-perilaku yang dipelajari, yang digunakan oleh individu pada situasi-situasi interpersonal dalam lingkungan.

Social Skill Training (SST) mengajarkan tiga kemampuan sosial yakni: (1) kemampuan berkomunikasi, yaitu bagaimana kemampuan menggunakan bahasa tubuh yang tepat, mengucapkan salam, memperkenalkan diri, menjawab pertanyaan, menginterupsi pertanyaan dengan baik, dan kemampuan bertanya; (2) kemampuan menjalin persahabatan, yaitu menjalin pertemanan, mengucapkan dan menerima ucapan terima kasih, memberikan dan menerima pujian, terlibat dalam aktivitas bersama, berinisiatif melakukan kegiatan dengan orang lain, meminta dan memberikan pertolongan; (3) kemampuan dalam menghadapi situasi sulit, yaitu memberikan kritik dan menerima penolakan, bertahan dalam tekanan kelompok dan minta maaf (MqQuaid, 2000).

\section{Metode Asesmen}

Metode asesmen yang digunakan adalah observasi, wawancara, dan tes psikologi. Observasi dilakukan pada saat wawancara dan observasi keadaan keluarga pada waktu berkunjung ke rumah subjek. Tujuan dari penggunaan metode observasi untuk melihat pola perilaku subjek sehari-hari. Wawancara dilakukan dengan subjek (Autoanamnesa) dan keluarga, perawat, dokter (Alloanamnesa) yang bertujuan untuk mengumpulkan data yang terkait dengan subjek.

Tes psikologi meliputi tes Grafis yang diberikan terdiri dari BAUM, House Tree Person, Drawing A Person untuk mengungkap kepribadian dan dinamika subjek yang berkaitan dengan permasalahannya. Tes psikologi Wescler Adult Inteligence Scale (WAIS) yang digunakan untuk memprediksikan potensi-potensi psikologis penunjang dari
IQ itu sendiri yang dipengaruhi oleh faktor: lingkungan, latihan, motivasi, dan minat. Walaupun hasil dari tes WAIS ini berupa angka intelegensi, baik yang berupa Full IQ, Verbal IQ maupun Performance IQ, namun diketahui juga bahwa sub tes yang terdapat dari tes WAIS dapat digunakan untuk memprediksi permasalahan klinis yang dialami oleh subjek, baik untuk memprediksikan kemungkinan adanya brain damage, cronic alkoholism, maupun mental retarded. Tes psikologi Sack's Sentence Completion Test (SSCT) digunakan untuk mengungkap masalah-masalah yang muncul pada diri subjek

\section{Presentasi Kasus}

Subjek seorang laki-laki berusia 18 tahun merupakan anak pertama dari 2 bersaudara. Tinggi badan sekitar $165 \mathrm{~cm}$ dan berat badan subjek $50 \mathrm{~kg}$. Subjek dibawa ke RSJ Menur karena tiga hari sebelumnya subjek tidak mau berbicara dan makan. Subjek hanya mematung dan mengurung diri di kamar.

Berdasarkan hasil wawancara yang telah dilakukan, banyak data yang diperoleh dari orang tuanya. Menurut orang tuanya, subjek merupakan seorang yang sangat pendiam sejak kecil, jarang berinterakasi dengan orang lain dan lebih sering berada di rumah, terutama di kamarnya. Sejak kecil subjek menghabiskan waktunya di rumah neneknya, subjek dititipkan orang tuanya untuk tinggal di rumah neneknya dikarenakan kedua orang tua subjek sibuk bekerja dan pulang hingga malam hari. Ayah subjek bekerja sebagai koki di salah satu kantin, sedangkan ibu bekerja di salah satu jasa laundry.

Subjek tidak memiliki teman di lingkungan sekitarnya, subjek tumbuh dan hanya berinteraksi dengan neneknya. Nenek subjek sehari-harinya banyak menghabiskan waktu untuk menonton TV dan di kamar karena faktor usia dan juga sering sakit-sakitan, sehingga subjek pun tidak mendapatkan pola asuh yang baik. Subjek berangkat sekolah biasanya diantarkan ayahnya sebelum berangkat kerja. Subjek juga tidak memiliki teman di sekolah karena subjek kurang bisa berpartisipasi dalam lingkungan sosial. Berbeda dengan adik subjek yang dititipkan di tempat bibinya, banyak saudara dan teman bermain di lingkungan sosial, sehingga bisa belajar berinteraksi dengan baik.

Subjek terkenal sangat pendiam dan terlihat enggan berinteraksi sosial. Pertama kali memasuki Sekolah Menengah Pertama subjek mengaku banyak permasalahan, mulai dari kesulitan berinteraksi dengan teman baru sehingga subjek sering membolos sekolah karena merasa tidak memiliki teman. Biasanya subjek pergi membolos ke warnet, sampai pada akhirnya subjek dikeluarkan dari sekolah tersebut. Semenjak keluar dari sekolah, subjek hanya berada di rumah neneknya, tidak memiliki kegiatan dan juga jarang berinteraksi dengan orang lain. Subjek hanya menghabiskan waktu sehari-hari dengan menonton tv dan berada di kamar. Orang tua subjek takut jika subjek disekolahkan lagi maka terulang kejadian serupa. Orang tua subjek juga jarang mengajak 
berkomunikasi dikarenakan kesibukan bekerja. Subjek merasa kebingungan dengan jati diri subjek.

Pasien psikotik biasanya berasal dari keluarga dengan pola asuh disfungsi. Perilaku keluarga yang patologis secara signifikan meningkatkan stres emosional yang harus dihadapi oleh pasien psikotik. Pola asuh merupakan pola interaksi antara orang tua dan anak. Termasuk cara menerapkan aturan, mengajarkan nilai atau norma, memberikan perhatian dan kasih sayang serta menunjukkan sikap dan perilaku yang baik sehingga dijadikan contoh atau panutan bagi anaknya. Pola asuh yang dilakukan orang tua menjadikan anak belajar tentang banyak hal termasuk karakter. Subjek dan orang tua mengaku bahwa memang jarang berkomunikasi sejak kecil dikarenakan di rumah hanya ada nenek dan orang tua kerja dari pagi sampai malam sehingga jarang terjadi interaksi dan komunikasi di antara orang tua dan anak.

Menurut sudut pandang behavioral, skizofrenia terjadi dikarenakan salah satunya berkaitan dengan pola asuh orang tua yang diterapkan kepada anaknya, yaitu berupa pola asuh patogenik. Skizofrenia berasal dari perilaku keluarga, terutama keluarga patologis, yang secara signifikan meningkatkan stres emosional yang harus dihadapi oleh pasien skizofrenia. Menurut pandangan ini anak-anak yang nantinya mengalami skizofrenia mempelajari reaksi dan cara berpikir yang tidak rasional dengan mengimitasi orang tua yang juga memiliki masalah emosional yang signifikan. Hubungan interpersonal yang buruk dari pasien skizofrenia berkembang karena pada masa anak-anak mereka belajar dari model yang buruk. Stimulus seperti kritik, sifat kejam, dan sangat ingin ikut campur urusan anak dapat membuat anak memberikan respon yang sama bila dihadapkan pada situasi yang serupa.

Subjek mengatakan bahwa sejak kecil subjek memang jarang berkomunikasi dengan kedua orang tuanya, hal ini juga sesuai dengan hasil tes grafis subjek yang menggambarkan figur orang tua yang tidak berfungsi. Pada saat subjek membolos sekolah dan memiliki permasalahan sosialisasi di sekolah tidak ada tempat bercerita di rumah. Subjek juga memiliki keinginan bersekolah lagi dan menyesal karena pernah membolos sehingga dikeluarkan dari sekolah. Hal itu sejalan dengan hasil SSCT yang memperlihatkan ketakutan-ketakutan subjek terhadap permasalahan yang sedang dia hadapi.

Dinamika terbentuknya gangguan skizofrenia pada subjek yang dilihat dari faktor penyebabnya dapat dijelaskan melalui model diatesis stres. Berdasarkan perspektif diatesis stres, individu dapat mengalami gangguan patologis seperti psikotik disebabkan oleh adanya interaksi antara kerentanan genetik, kepribadian dan stresor lingkungan (Davison \& Neale, 2006). Teori diathesis stress menjelaskan bahwa gangguan yang dialami seseorang dapat dipengaruhi oleh faktor genetis atau neurotis, lingkungan dan psikologis.

Berdasarkan teori diatesis stres, penyebab terjadinya gangguan pada diri subjek karena kerentanan psikologis yaitu masalah kepribadiannya. Kepribadian subjek yang tertutup, cenderung pasif dalam tindakan dan sangat bergantung pada dorongan serta perhatian orang lain membuat subjek mudah tertekan ketika menghadapi stressor. Kemampuan sosial subjek yang rendah membuat subjek menarik diri dari lingkungan sekitar. Faktor lingkungan juga mendukung seperti pola asuh sangat permisif membuat subjek tidak tahu dan tidak pernah belajar mengenai koping stres.

Memiliki diatesis dapat meningkatkan resiko seseorang mengalami gangguan. Selain itu secara umum stres juga dapat mengarah pada stimulus yang menyebabkan psikopatologis. Dalam diathesis stres gangguan yang dialami seseorang tidak mungkin disebabkan oleh faktor tunggal namun ada faktor lainnya yang juga berperan dalam gangguan. Faktor - faktor tersebut seperti karakteristik kepribadian, pengalaman masa kecil, strategi menghadapi stres, stresor yang dialami dimasa dewasa serta berbagai faktor lainnya (Davison \& Neale, 2006). Model diathesis stres memandang skizofrenia sebagai interaksi atau kombinasi dari diatesis, dalam bentuk predisposisi genetis maupun psikologis untuk berkembangnya gangguan dengan stres lingkungan yang melebihi batas atau koping individu. Stressor lingkungan mencakup konflik keluarga, perlakuan yang salah terhadap anak, atau kehilangan figur yang memberikan dukungan dan lain sebagainya (Nevid, 2005).

Dinamika terbentuknya masalah pada subjek dapat dijelaskan melalui perspektif behavioral. Perspektif behaviorisme mengemukakan bahwa individu dan lingkungan merupakan dua hal yang saling berkaitan dan memengaruhi satu sama lain untuk menciptakan sebuah perilaku (Bandura, 1977). Dalam hal ini lingkungan subjek tidak memberikan hal positif terhadap subjek, seperti orang tua subjek acuh dan permisif karena jarang berkomunikasi sehingga subjek menjadi sosok yang tertutup dan lebih banyak menghabiskan waktu di dalam kamar, subjek juga tidak ada komunikasi dengan keluarga atau lingkungan sekitarnya, subjek juga tidak memiliki kesempatan untuk mengungkapkan pendapatnya.

Hal-hal di atas membuat subjek menjadi seseorang yang kurang dalam hal keterampilan sosialnya, terbukti saat di RSJ subjek lebih sering berada di kamar dan enggan untuk berinteraksi dengan lingkungan sekitar. Keterampilan sosial adalah kemampuan individu untuk berkomunikasi efektif dengan orang lain baik secara verbal maupun nonverbal sesuai dengan situasi dan kondisi yang ada pada saat itu, di mana keterampilan ini merupakan perilaku yang dipelajari. Keterampilan sosial mengajarkan tiga kemampuan sosial yakni: (1) kemampuan berkomunikasi, (2) kemampuan menjalin pertemanan, (3) kemampuan dalam menghadapi situasi sulit (MqQuaid, 2000). Dalam kasus intervensi hanya fokus pada kemampuan menjalin pertemanan seperti mampu menyapa, memperkenalkan diri, berkomunikasi ringan dengan lingkungan sekitar. 
Keterampilan sosial sejalan dengan teori belajar sosial dari Bandura yang mengemukakan bahwa individu mempelajari sesuatu melalui pengalaman langsung atau observasi. Dalam intervensi menggunakan teknik modeling agar subjek mampu mempelajari hal baru dengan cara mencontoh perilaku yang ada di sekitarnya (Bandura, 1986). Menurut Bandura proses mengamati dan meniru perilaku dan sikap orang lain sebagai model merupakan tindakan belajar. Teori Bandura menjelaskan perilaku manusia dalam konteks interaksi timbal balik yang berkesinambungan antara kognitif, perilaku dan pengaruh lingkungan. Kondisi lingkungan sekitar individu sangat berpengaruh pada pola belajar sosial jenis ini.

Proses pengamatan pada teori belajar sosial tentunya tidak berlangsung begitu saja, melainkan melibatkan fungsi kognitif individu. Oleh sebab itu, perilaku sederhana cenderung mudah untuk ditiru (Bandura, 1989). Proses pengamatan dan pembelajaran keterampilan sosial dalam bentuk sederhana ini diharapkan mampu diikuti dengan baik oleh subjek agar dapat mengalihkan pemikiran negatifnya.

\section{Diagnosis dan Prognosis}

\section{Diagnosis}

Berdasarkan uraian kasus, dengan pedoman Diagnostic and Statistical Manual of Mental Disorder Fifth Edition (DSM-V) (American Psychiatry Association, 2010) maka dapat ditegakkan diagnosis bahwa subjek memenuhi kriteria diagnostik Gangguan Skizofrenia Katatonik 293.89 (F06.1) yang ditandai dengan adanya halusinasi dan perilaku katatonik seperti stupor dan mematung, gelisah dan rigiditas (mempertahankan posisi tubuh) dengan permasalahan keterampilan sosial, yang menyebabkan klien menarik diri dari lingkungan sosialnya dan kesulitan menjalin hubungan dengan orang lain.

\section{Prognosis}

Berdasarkan permasalahan yang dialami subjek maka dapat diperkirakan subjek memiliki prognossis baik, hal ini didasari oleh faktor yang melatarbelakangi, yaitu keinginan subjek sembuh dan ingin bersekolah lagi. Subjek juga bersikap kooperatif terhadap terapis sehingga bisa memahami instruksi-instruksi dengan baik, selain itu karena adanya kontribusi dan peran keluarga yang sangat mendukung intervensi.

\section{Intervensi}

Intervensi yang digunakan adalah Social Skills Training (SST). SST mengacu pada empat tahapan yang dikemukakan oleh Stuart \& Laraia (2005)yakni melatih kemampuan klien berkomunikasi, menjalin persahabatan dan menghadapi situasi sulit, dengan menggunakan metode modelling, role play, feedback dan transfer training. Sistem tersebut teridentifikasi oleh tindakan dan perilaku yang teratur dan terkontrol oleh faktor - faktor biologis, psikologis, dan sosiologis.

Social Skills Training (SST) merupakan terapi perilaku dengan target untuk meningkatkan keterampilan sosial seperti menyapa, memperkenalkan diri dan berkomunikasi ringan dengan lingkungan. Terapi perilaku berupa keterampilan sosial merupakan salah satu intervensi dengan teknik modifikasi perilaku yang didasarkan pada prinsipprinsip bermain peran, praktek dan umpan balik guna meningkatkan kemampuan klien dalam menyelesaikan masalah pada klien depresi, skizofrenia, klien dengan gangguan perilaku kesulitan berinteraksi, mengalami fobia sosial dan klien yang mengalami kecemasan (Kneisl, 2004; Varcarolis, 2006; Stuart \& Laraia, 2005). Intervensi dilakukan tujuh sesi :

Sesi I: Membangun rapport dengan subjek. Pada sesi ini terapis berusaha membuat subjek nyaman dan percaya kepada terapis agar intervensi tersebut berjalan dengan lancar.

Sesi II : Orientasi pengenalan terapi dan identifikasi pemicu masalah. Pada sesi ini subjek dikenalkan tentang terapi yang terapis berikan yaitu berupa pelatihan keterampilan sosial. Terapis juga menjelaskan prosedur apa saja yang dilalui oleh subjek selama terapi dan subjek harus memperhatikan instruksi yang terapis berikan. Pada sesi ini juga terapis mengajak subjek membuat target perubahan yang ingin dicapai yaitu untuk meningkatkan keterampilan sosial subjek yang meliputi mampu mengucap salam, memperkenalkan diri, dan berkomunikasi ringan dengan lingkungan sekitar. Pada sesi ini terapis meminta subjek untuk mengenali masalah atau situasi yang dapat membuat subjek memilih untuk menarik diri dan berdiam diri di dalam kamar. Terapis juga memberikan penjelasan tentang dampak yang terjadi jika subjek memilih untuk menarik diri dan berdiam diri di dalam kamar setelah menonton video.

Sesi III: Modelling. Terapis mengajarkan subjek keterampilan dengan cara memberikan contoh terlebih dahulu. Terapis mencontohkan bagaimana cara menyapa, berkenalan dan menanyakan kabar kepada orang-orang yang berada dalam lingkungan bangsal subjek, kemudian terapis menyuruh subjek untuk memperhatikan apa yang terapis lakukan agar dapat dicontoh dan dilakukan. Pada sesi ini subjek mengamati bagaimana cara berinteraksi ringan yang terapis contohkan seperti bagaimana cara tersenyum, menyapa, berkenalan dan menanyakan kabar orang-orang yang berada di lingkungan subjek agar dapat dipraktekkan pada sesi selanjutnya.

Sesi IV: Bermain peran. Terapis meminta subjek untuk mencoba menghampiri orang yang yang berada di sekitarnya, kemudian subjek diminta senyum lebih dulu kepada orang tersebut, menyapa, berkenalan, menanyakan kabar. 
Sesi V: Pemberian Tugas. Terapis meminta subjek melakukan interaksi dengan lingkungan subjek tanpa ditemani oleh terapis. Terapis juga meminta subjek agar dapat berkomunikasi ringan dengan orang-orang sekitar subjek. Setelah 4 kali pertemuan subjek baru mampu melakukan tugas yang diberikan oleh terapis dengan baik. Subjek mampu berkomunikasi ringan dengan orang-orang sekitar subjek, sehingga subjek tidak hanya berada di dalam kamar

Sesi VI: Evaluasi. Terapis mengevaluasi kegiatan yang di lakukan oleh subjek. Terapis memberikan umpan balik kepada subjek dan memberikan penguatan terus menerus kepada subjek dengan mengatakan bahwa apa yang telah subjek lakukan sudah baik dan benar agar subjek mampu memenuhi target perubahan yang telah dibuat. Subjek sudah mulai mampu menyapa, berkenalan bahkan menanyakan kabar, sehingga subjek merasa tidak sendiri dan memiliki banyak teman orang yang sayang dan peduli kepada subjek.

Sesi VII: Terminasi. Pada sesi ini terapis menyimpulkan hal-hal yang telah dipelajari oleh subjek selama proses intervensi, memberikan bekal perilaku agar subjek mau membiasakan diri untuk bersosialisasi dengan lingkungan dan meningkatkan interaksi sosial agar subjek merasa tidak sendiri dalam menghadapi masalah. Terapis juga meminta pada perawat untuk tetap mengontrol subjek meskipun proses intervensi sudah berakhir. Terminasi ini dilakukan agar target perubahan yang diinginkan yaitu ketika keterampilan sosial subjek untuk meningkatkan interaksi sosial sudah meningkat.

Sesi VIII: Follow-up. Follow-up dua minggu setelah intervensi berakhir dilakukan untuk mengetahui perkembangan subjek dalam interaksinya terhadap lingkungan sosial subjek. Saat follow up subjek bahkan sudah sering berkomunikasi bahkan menjalin pertemanan dengan orang-orang

\section{Hasil dan Pembahasan}

\section{Hasil}

Berdasarkan pelaksanaan intervensi yang telah dilakukan, subjek sudah mulai menunjukkan perubahan secara bertahap. Setelah intervensi subjek yang awalnya lebih banyak diam dan sering mengurung diri di dalam kamar sudah mau untuk keluar kamar dan berinteraksi dengan orang di sekitar. Subjek juga sudah mau mulai menyapa dan mengajak berkenalan orang yang berada di sekeliling subjek, subjek juga sudah mulai terlibat obrolan dengan keluarga dan sepupu-sepupu nya yang berada dirumah.

Subjek menyadari bahwa sikap subjek yang selama ini hanya diam, tertutup dan enggan berkomunikasi dengan orang-orang di lingkungan sekitar subjek merupakan hal yang kurang tepat. Perubahan yang terjadi pada diri subjek ini didukung oleh keinginan subjek untuk merubah sikapnya agar dapat berinteraksi dengan orang lain dan bisa bersekolah lagi seperti anak seusia subjek. Selain faktor tersebut keberhasilan intervensi ini juga karena adanya dukungan dari lingkungan sekitar seperti nenek subjek, bibi subjek dan beberapa sepupu-sepupu subjek yang mendukung dan membantu agar subjek mampu untuk melaksaan intervensi ini sehingga membuat subjek merasa diterima dan merasa tidak sendiri dan banyak yang menyayangi subjek.

\section{Pembahasan}

Dalam Social Skill Training (SST) ini terapis berperan sebagai model yang memberikan contoh bagaimana berinteraksi dengan lingkungan sekitar dari bagaimana cara berkenalan sampai berkomunikasi ringan dengan lingkungan sekitar yang harus subjek pelajari dan kemudian diterapkan. Menurut Bandura terdapat empat proses yang terlibat di dalam pembelajaran melalui pendekatan modeling, yaitu perhatian (attention), pengendapan (retention), reproduksi (reproduction), dan penguatan (motivasi).

Pada tahap attention dan retention yaitu tahap melihat dan penyerapan informasi subjek meniru tingkah laku dan disimbolisasikan dalam ingatan, baik dalam bentuk verbal maupun dalam bentuk gambaran/imajinasi. Attention verbal memungkinkan orang mengevaluasi secara tingkah laku yang diamati dan menentukan mana yang dibuang dan mana yang dilakukan. Representasi imajinasi memungkinkan dapat dilakukannya latihan simbolik dalam fikiran, tanpa benar-benar melakukannya secara fisik. Saat proses intervensi berlangsung subjek diajarkan untuk memikirkan bahwa semua orang yang ada di sekitar subjek adalah orang yang baik dan menyenangkan.

Pada tahap produksi, individu diajarkan untuk menerapkan perilaku yang telah dipelajari ke lingkungan nyata sehari-hari (Bandura, 1986). Setelah mengetahui atau mempelajari sesuatu tingkah laku, subjek harus mempunyai keahlian untuk mewujudkan atau menghasilkan apa yang disimpan dalam bentuk tingkah laku. Proses intervensi subjek diberikan tugas oleh terapi untuk menerapkan apa yang telah terapis ajarkan dalam kehidupan subjek sehari hari. Meskipun tidak mudah tetapi karena lingkungan sekitar subjek mendukung maka tugas tersebut dapat dilaksanakan dengan baik.

Pada tahap terakhir yaitu motivasi, dimana terapis memberikan motivasi yang tinggi terhadap subjek untuk dapat melakukan tingkah laku modelnya. Observasi dapat memudahkan individu untuk menguasai tingkah laku tertentu, tetapi jika motivasi untuk itu tidak ada, maka tidak terjadi proses belajar. Selama proses belajar berlangsung, pemberian penguatan positif dari lingkungan sekitar dirasa mampu meningkatkan motivasi individu untuk memperkuat perilaku baru yang dipelajari (Bandura, 1989).

Secara keseluruhan, perubahan dapat terjadi karena individu telah menjalani proses belajar yang melibatkan unsur pengamatan, adanya pemberian pengetahuan mengenai konsekuensi tentang pemikiran negatifnya, dan latihan 
agar memperoleh keterampilan perilaku baru yang secara terus-menerus (Bandura, 1977).

\section{Simpulan}

Berdasarkan hasil intervensi yang telah dilakukan, scheduling activity dapat menigkatkan motivasi subjek untuk beraktivitas pada waktu luang. Namun penerapan intervensi tersebut memerlukan dukungan dari lingkungan sekitar serta pengawasan yang cukup intens. Subjek dapat memiliki inisiatif untuk beraktivitas di waktu luang.

\section{Referensi}

American Psychiatry Association. (2010). Diagnostic and Statistical Manual of Mental Disorders fifth edition. Washington DC: American Psychiatry Association.

Bandura, A. (1977). Social learning theory. New Jersey: PrenticeHall.

Bandura, A. (1986). Social foundations of thought and action: A social cognitive theory. New Jersey: Prentice-Hall.

Bandura, A. (1989). Social cognitive theory. In R. Vasta (Ed.). Annals of child development, vol.6. Six theories of child development (pp.1-60). Greenwich, CT:JAI Press.

Corey, Gerald. (1999). Teori dan praktek konseling dan psikoterapi. Bandung:PT Refika Aditama.

Davison, G.C \& Neale J.M. (2006). Psikologi Abnormal. Jakarta: PT. Raja Grafindo Persada.
Gimpel, G.A. \& Merrell, K.W. (1998). Social skill of children and adolescents: conceptualization, assessment, treatment. New Jersey: Lawrence Erlbaum Associates Publisher.

Kendal, P.C. \& Hammen, C., (1998). Abnormal psychology understanding human problem. New York : Houghton Mifflin Company

Kneisl, C. R, Wilson, H. S. \& Trigoboff, E. (2004). Contemporary psychiatric mental health nursing. New Jersey: Pearson Prentice Hall.

Maramis, WF. (2009). Catatan ilmu kedokteran jiwa. Surabaya: Airlangga University Press

MqQuaid. (2000). Development of an integrated cognitivebahavior and social skill training intervention for older patients with schizoprenia. The Journal of Psychotherapy Practise and Research, 9 (3), 149-156. https://pmid:org. 10896740

Nevid, J., Rathus S., \& Beverly G. (2005). Psikologi abnormal. Jakarta: Penerbit Erlangga

Varcarolis, E.M. (2006). Psychiatric nursing clinical guide: assessment tools \& diagnosis. Philadelphia: W.B. Saunders Company.

Stuart, G.W \& Laraia,M.T. (2005). Principles and practice of psychiatric nursing. (7th Edition). St.Louis: Mosby.

Videbeck, SL. (2008). Buku ajar keperawatan jiwa. Penerbit buku kedokteran EGC: Jakarta. 